\title{
ANALISIS ASUHAN KEPERAWATAN DENGAN PENERAPAN TINDAKAN "SLOW STROKE BACK MASSAGE" PADA PASIEN KANKER SERVIKS DENGAN MASALAH KEPERAWATAN UTAMA NYERI PINGGANG DI RUANG TERATAI RUMAH SAKIT PROF. DR. MARGONO SOEKARJO PURWOKERTO
}

\author{
Mauizatul Hasanah ${ }^{1}$,Diah Astutiningrum ${ }^{1}$, Susio Maryati $^{2}$, Rasinah $^{1 *}$ \\ ${ }^{1}$ STIKES Muhammadiyah Gombong \\ ${ }^{2}$ RSUD Prof. Dr. Margono Soekarjo Purwokerto \\ *e-mail: gelisbergas@gmail.com
}

\begin{abstract}
Keywords:

Asuhan

Kanker servik akan menimbulkan rasa nyeri, apabila nyeri tidak segera

keperawatan; diatasi akan berdampak buruk bagi pasien. Penanganan non farmakologi

Terapi SSBM, yang bisa dilakukan untuk menangani nyeri adalah terapi pijat punggung

Kanker Servik,

Nyeri Kronis

$$
\text { sampai pinggang "Slow Stroke Back Massage" (SSBM). Tujuan studi }
$$

kasus ini adalah menjelaskan tindakan keperawatan terapi SSBM pada klien kanker servik dengan masalah nyeri pinggang kronis. Desain yang digunakan adalah studi kasus deskriptif dengan instrumen menggunakan kuisioner dan format asuhan keperawatan yang digunakan yaitu analisis isi. Analisis selanjutnya yaitu membandingkan asuhan keperawatan yang telah dilakukan pada pasien kelolaan dengan kriteria hasil dari NOC (nursing outcome classification). Penerapan inovasi keperawatan dengan terapi "Slow Stroke Back Massage"dilakukan dengan tehnik pijat punggung sampai pinggang selama kurang lebih selama 10-15 menit dengan frekuensi $1 x /$ hari dan dalam tempo 3 hari masa perawatan. Implementasi nonfarmakologi berupa tindakan "SSBM" sangat efektif dilakukan pada klien dengan keluhan nyeri pinggang. Observasi dilakukan selama 3 hari dengan hasil terjadi penurunan nyeri yang signifikan pada ke-3 klien, dengan penurunan skala 1-2, diukur menggunakan instrument skala nyeri "Numeric Rating Scale". Setelah dilakukan terapi semua klien merasa lebih nyaman, rileks serta dapat berisitirahat dengan tenang dimalam hari.
\end{abstract}

\section{PENDAHULUAN}

Kanker merupakan suatu jenis penyakit yang ditandai dengan pertumbuhan sel abnormal yang tidak bisa dikendalikan didalam tubuh manusia. Kanker menjadi penyebab kematian terbesar saat ini. Pada tahun 2015 terjadi peningkatan kasus kanker dikarenakan pola hidup yang salah, seperti kebiasan merokok, mengkonsumsi akohol, serta mengkonsumsi makanan yang banyak mengandung lemak jenuh (Safitri, dkk., 2018).
Kanker dapat dialami oleh pria maupun wanita. Kanker yang sering menyerang pada masyarakat khususnya kaum wanita hingga dapat menyebabkan kematian ialah kanker leher rahim atau mulut rahim, sering disebut dengan istilah medis kanker servik. Kanker servik atau kanker mulut rahim merupakan kanker yang paling berbahaya mengancam kehidupan seorang wanita. Berdasarkan estimasi data tersebut Provinsi Jawa Tengah merupakan provinsi dengan jumlah penderita kanker servik paling banyak, terdapat 90-100 
ribu kasus per 100.000 penduduk dan setiap tahun terdapat 40.000 kasus kanker servik (Sutrisno, 2018).

Tindakan pengobatan kanker servik dapat melalui tehnik farmakologi maupun non-farmakologi. kemoterapi merupakan terapi farmakologi bertujuan untuk menghancurkan sel-sel kanker yang menyerang tubuh. Cara kerja obat ini ialah dengan menghambat bahkan sampai menghentikan pertumbuhan sel kanker sehingga sel kanker tidak dapat tumbuh dan berkembang menjadi semakin luas (Grove, 2016). Akan tetapi, pada dasarnya walaupun kemoterapi merupakan terapi yang paling baik bagi penderita kanker servik, namun tidak dapat menutup kemungkinan bahwa pengobatan dari kemoterapi sendiri memiliki efek samping bagi penderita, baik efek samping mengarah kepada kondisi fisik maupun psikologis (World Health Organization, 2014).

Selain menyerang psikis, tak jarang kanker mulut rahim ini menyerang fisik. Ditinjau dari para penderita kanker servik, beberapa diantara mereka mengalami keluhan nyeri dibagian pinggang, kantung kemih serta bagian di atas organ kewanitaan. Nyeri merupakan keluhan utama penderita kanker servik disebabkan karena pertumbuhan tumor, efek dari prosedur diagnostik dan perawatan yang berulang. Nyeri yang dirasakan penderita kanker servik ialah dikarenakan lokasi kanker servik berdekatan dengan saraf panggul, jaringan lunak dan struktur tulang sehingga kanker cenderung untuk menyebar menuju struktur retroperitoneal, sehingga mengakibatkan nyeri yang semakin meningkat (Setyowati, dkk, 2019).

Salah satu terapi nonfarmakologis untuk mengurangi rasa nyeri yang dirasakan oleh penderita kanker servik yaitu dengan terapi slow stroke back massage (SSBM). Terapi SSBM merupakan suatu tindakan stimulasi kulit untuk memberi kenyamanan, meredakan ketegangan, merilekskan badan, serta meningkatkan sirkulasi darah didalam tubuh. Mekanisme terapi pijat punggung atau yang disebut "slow stroke back massage" diawali dengan pijat di daerah punggung dan merangsang titik tertentu di sepanjang medulla spinalis yang ditransmisikan melalui serabut saraf besar ke formation retikularis, thalamus serta sistem limbik tubuh yang akan melepaskan hormon endorphin. Endorphin merupakan neurotransmitter yang dapat menghambat pengiriman rangsang nyeri dengan cara menempel kebagian reseptor opiate pada saraf dan sumsum tulang belakang sehingga dapat menghambat pesan nyeri ke pusat yang lebih tinggi dan dapat menurunkan sensasi nyeri (Setyowati, 2019). Massase dapat meningkatkan relaksasi pada tubuh, juga merupakan asuhan efektif, aman, sederhana dan tidak menimbulkan efek yang merugikan bagi pasien.

Hasil studi pendahuluan di ruang Teratai RSMS Purwokerto pada 3 bulan terakhir didapatkan hasil bahwa, terdapat sejumlah pasien wanita mengalami kanker servik sebanyak 74 jiwa. Dari 74 jiwa tersebut dilakukan intervensi awal, yakni massase punggung hingga pinggang, dengan hasil dari 2 responden dengan kanker serviks stadium 3 menunjukkan hasil adanya penurunan skala nyeri dengan skala awal 4 menjadi skala 3 selama 3 hari dilakukan tindakan. Adanya hasil dari penerapan tindakan massase tersebut menandakan tindakan pijat atau massage "SSBM" efektif dilakukan pada pasien penderita kanker serviks stadium 3 dengan nyeri pinggang kronis. "Slow Stroke Back Massage", diyakini salah satu inovasi yang dapat membantu penderita meringankan rasa pegal atau sakit di bagian pinggang.

Meningkatnya jumlah penderita kanker serviks akhir-akhir ini sangat mengkhawatirkan dunia kesehatan. Dampak dari kanker serviks tidak hanya pengangkatan dari organ kewanitaan namun dapat sampai merenggut nyawa penderitanya. Tanda dan gejala dari penderita kanker servik salah satunya ialah nyeri dibagian pinggang, rasa nyeri ataupun pegal yang dirasakan penderita kanker serviks sangat menganggu aktivitas bahkan konsentrasi dan tidak dipungkiri akan menganggu aktivitas organ lain seperti pencernaan ataupun perkemihan, sehingga dibutuhkan inovasi keperawatan untuk membantu meringankan beban nyeri yang 
dirasakan penderita kanker serviks tersebut. Penulis tertarik untuk melakukan asuhan keperawatan pada pasien kanker serviks stadium dini_dengan penerapan "slow stroke back massage" untuk menurunkan nyeri pinggang di Ruang Teratai RSUD. Prof. Dr. Margono Soekarjo Purwokerto.

Tujuan karya ilmiah ini yaitu menjelaskan asuhan keperawatan dengan penerapan tindakan "Slow Stroke Back Massage"pada pasien kanker servik dengan masalah keperawatan utama nyeri pinggang di ruang Teratai Rumah Sakit Prof. Dr. Margono Soekarjo Purwokerto.

\section{METODE}

Desain penelitian menggunakan studi kasus deskriptif. Instrumen penelitian menggunakan kuisioner, yang berisi identitas responden, lembar pengkajian nyeri menggunakan skala ukur numerik (NRS), lembar observasi pre dan post intervensi "Slow Stroke Back Massase". Format asuhan keperawatan yang digunakan yaitu analisis isi. Data yang telah ditemukan pada saat pengkajian dikelompokkan dan dianalisis berdasarkan data subyektif dan obyektif, sehingga dapat dirumuskan diagnosa keperawatan, kemudian menyusun rencana atau intervensi keperawatan dan melakukan implementasi serta evaluasi keperawatan pada pasien kanker servik. Analisis selanjutnya yaitu membandingkan asuhan keperawatan yang telah dilakukan pada pasien kelolaan dengan kriteria hasil dari NOC (nursing outcome classification).

\section{HASIL STUDI KASUS}

Responden dalam studi kasus ini berjumlah tiga pasien dengan kanker servik di Ruang Teratai Rumah Sakit Prof. Dr. Margono Soekarjo Purwokerto. Berikut hasil studi kasus dari tiga pasien.

Tabel 1. Hasil Penerapan Tindakan Slow Stroke Back Massage

\begin{tabular}{ccccc}
\hline \multirow{2}{*}{ Klien } & \multirow{2}{*}{$\begin{array}{c}\text { Usia } \\
\text { (tahun) }\end{array}$} & $\begin{array}{c}\text { Hari } \\
\text { ke-1 }\end{array}$ & $\begin{array}{c}\text { Hari } \\
\text { ke-2 }\end{array}$ & $\begin{array}{c}\text { Hari } \\
\text { ke-3 }\end{array}$ \\
\hline Klien 1 & 60 & 4 & 3 & 2 \\
\hline Klien 2 & 29 & 5 & 4 & 3 \\
\hline Klien 3 & 44 & 5 & 4 & 3 \\
\hline
\end{tabular}

Berdasarkan hasil asuhan keperawatan pada tiga pasien didapatkan masalah keperawatan nyeri kronis. Penulisan rencana asuhan keperawatan dituliskan berdasarkan Nursing Outcome Clasifications (NOC) dan Nursing Intervention Clasifications (NIC) yaitu sebagai berikut: Tujuan: setelah dilakukan tindakan keperawatan selama 1x24 jam dalam 3 hari masa perawatan diharapkan masalah nyeri akut dapat teratasi dengan kriteria hasil: mengenali kapan nyeri terjadi, gunakan tindakan pengurangan nyeri tanpa analgesic, gunakan analgesic yang direkomendasikan dan melaporkan gejala yang tidak terkontrol, nyeri yang dilaporkan, menggosok area yang terkena dampak, mengerang atau menangis, ekspresi wajah nyeri, mengerinyit, fokus menyempit, dan kehilangan nafsu makan.

Intervensi yang dilakukan berdasarkan NIC yaitu Manajemen Nyeri: lakukan pengkajian secara komprehensif, bantu keluarga dalam mencari dan menyediakan dukungan, dorong pasien untuk memonitor nyeri dan menangani nyeri dengan tepat, ajarkan penggunaan teknik non farmakologi, ajarkan metode farmakologi untuk menurunkan nyeri, serta kolaborasi dengan pasien, orang terdekat dan tim kesehatan untuk mengimplementasikan tindakan penurunan nyeri non farmakologi. Terapi non farmakologi yang telah dilakukan dalam studi kasus ini yaitu Slow stroke back massage "SSBM"/ terapi pijat punggung sampai pinggang.

Penerapan yang telah dilakukan mengalami penurunan intensitas nyeri pada ketiga pasien dengan karakteristik responden yang berbeda seperti pada tabel 1. Hal tersebut menunjukan adanya kenyamanan pada setiap pasien setelah dilakukan Slow stroke back massage yang didukung dengan lingkungan yang nyaman, keluarga dan konsentrasi pada setiap pasien.

\section{PEMBAHASAN \\ Analisis Karakteristik Klien}

Penulis mengambil tiga klien dengan diagnosa medis kanker servik dengan masalah keperawatan utama nyeri akut, akan tetapi dengan karakteristik klien yang 
berbeda-beda. Hasil data yang diperoleh melalui rekam medis dan klien didapatkan pada klien 1, usia 60 tahun, jenis kelamin perempuan, pendidikan SD, diagnosa medis kanker servik, klien 2, usia 29 tahun, jenis kelamin perempuan, pendidikan terakhir SMA, diagnose medis kanker servik, selanjutnya pada klien 3, usia 44 tahun, pendidikan terakhir SMA, diagnosa medis kanker servik. Ketiga klien memiliki skala nyeri yang berbeda namun dalam satu kategori yaitu nyeri ringan-sedang. Pada klien pertama nyeri dengan skala 4, klien kedua dengan skala 5 dan klien ketiga dengan skala 5. Hal tersebut menunjukkan perbedaan tingkat nyeri, akan tetapi respon ketiga klien terhadap nyeri berbeda-beda, ada yang menerima nyeri dan ada yang tidak bisa menahan nyeri.

Usia merupakan variabel terpenting yang dapat mempengaruhi nyeri khususnya pada setiap individu, baik anak-anak, dewasa maupun lansia. Semakin bertambahnya usia pada seseorang maka semakin bertambah pula pemahaman terhadap suatu masalah yang diakibatkan oleh tindakan dan memiliki usaha untuk mengatasinya. Pada lansia yang mengalami nyeri perlu dilakukannya pengkajian, diagnosis dan penatalaksanaan secara agresif. Individu lanjut usia memiliki resiko tinggi mengalami situasi yang membuat mereka merasakan nyeri. Namun, klien lansia juga tidak dapat melaporkan nyeri karena yakin bahwa nyeri merupakan sesuatu yang mereka harus menerima dan akibat alamiah dari proses penuaan sehingga mereka akan mengabaikan perasaan tersebut (Potter \& Perry, 2010). Kelompok usia produktif rentang terhadap kejadian nyeri karena aktivitas dan mobilitas yang tinggi dari setiap individu.

Karakteristik responden pada studi kasus ini berjenis kelamin perempuan. Pada umumnya wanita akan menunjukkan ekspresi emosional yang lebih kuat pada saat mengalami nyeri seperti menangis. Karakter jenis kelamin dan kaitannya dengan keterpaparan dan tingkat kerentanan memegang peranan tersendiri seperti lakilaki tidak pantas mengeluh nyeri dan perempuan pantas mengeluh nyeri
(Sjamsuhidajat, 2008). Hal tersebut terjadi karena laki-laki lebih siap dalam menerima efek atau dampak, komplikasi dari nyeri sedangkan perempuan suka mengeluhkan sakitnya dan menangis (Adha, 2014).

Pengalaman nyeri yang dirasakan pada ketiga klien berbeda-beda, sehingga dapat berpengaruh terhadap intensitas dan respon terhadap nyeri. Beberapa klien yang lebih mudah menerima nyeri dibandingkan dengan klien lain, akan bergantung pada keadaan dan interpretasi klien mengenai makna nyeri tersebut. klien yang mengubungkan rasa nyeri dengan hasil akhir yang postif dapat menahan nyeri dengan baik, begitupun sebaliknya apabila nyeri tidak mereda dapat merasa lebih menderita karena mereka tidak dapat menghubungkan makna positif atau tujuan nyeri (Kozier, 2011).

Tingkat seorang individu dalam memfokuskan perhatiannya pada nyeri dapat mempengaruhi persepsi nyeri. Perhatian yang meningkat dihubungkan dengan nyeri yang meningkat, sedangkan upaya pengalihan (distraksi) dihubungkan dengan respon nyeri yang menurun. Klien yang mengalami nyeri seringkali bergantung pada anggota keluarga atau teman untuk memperoleh dukungan, bantuan, atau perlindungan. Apabila tidak ada keluarga atau teman seringkali pengalaman nyeri membuat pasien semakin tertekan (Potter \& Perry, 2010). Penelitian yang dilakukan oleh Wijaya (2015) bahwa sikap dan keyakinan positif menjadi faktor pendukung dalam menurunkan intensitas nyeri pada pasien post operasi dibandingkan dengan sikap dan keyakinan yang negatif.

\section{Analisis Asuhan Keperawatan Utama}

Berdasarkan analisis tindakan keperawatan pada ketiga pasien dengan diagnosa keperawatan utama nyeri akut berhubungan dengan agen cedera fisik, dalam hal ini penulis memberikan terapi non farmakologis berupa mengatur keadaan lingkungan klien dengan meminimalisir kunjungan dan jumlah subyek dalam ruangan perawatan klien, serta mengatur keadaan pencahayaan dan suhu ruangan, tindakan tersebut dapat membantu mengurangi skala nyeri yang dikeluhkan oleh klien, hal ini 
dapat dibuktikan dari penelitian yang dilakukan oleh Hermanto (2020) yang berjudul "Upaya Penerapan Penurunan Nyeri Pada Pasien Post Operasi Fraktur Femur". Dari penelitian tersebut dijelaskan bahwa penurunan skala nyeri dapat dilakukan pada klien post operasi fraktur femur yaitu menutup lingkungan tempat tidur klien dengan sketsel sehingga klien merasa lebih nyaman dan dapat mengontrol skala nyeri post operasi yang dirasakan. Selain itu tindakan yang telah dilakukan pada ketiga klien yaitu mengatur posisi tidur, dari ratarata ketiga klien lebih suka dengan posisi semi fowler dikarenakan merasa lebih nyaman saat menghela nafas sehingga dapat mengontrol nyeri yang dirasakan pada daerah pinggang. Tindakan selanjutnya yaitu mengatur waktu istirahat klien dengan meminimalisis waktu kunjungan kepada klien, peneliti menjelaskan kepada klien serta keluarga bahwa pentingnya mengatur waktu istirahat demi kenyamanan kien serta membantu mengurangi nyeri yang dirasakan dengan memperbanyak waktu istirahat. Selain itu peneliti juga melakukan tehnik relaksasi kepada klien dengan tujuan mengurangi ketegangan otot pada daerah pinggang yang dirasakan nyeri oleh klien. Adapun inovasi tindakan non farmakologi yang telah diterapkan oleh peneliti yaitu tehnik pijat punggung sampai daerah pinggang atau sering disebut dengan "Slow Stroke Back Massage" untuk mengurangi tingkat atau skala nyeri pada klien. Setyowati (2019) menyatakan bahwa "Slow Stroke Back Massage" (SSBM) merupakan tehnik yang mempengaruhi sistem saraf otonom, apabila individu mempersepsikan sentuhan sebagai stimulus untuk rileks, kemudian akan muncul respon relaksasi. Relaksasi sangat penting untuk meningkatkan kenyamanan dan membebaskan diri dari ketegangan dan stress akibat penyakit yang dialami.

Pada penelitian yang dilakukan Sherwood dan Mander (2016), nyeri pinggang/punggung yang dirasakan oleh penderita kanker serviks dipercaya dapat diatasi dengan terapi "Slow Stroke Back Massage" (SSBM). Hal ini diperkuat dengan banyaknya penelitian mengenai inovasi pijat punggung tersebut. Massase pada pungung akan menghambat transmisi nyeri melalui serabut saraf besar ke formation retikularis, thalamus dan sistem limbik tubuh akan melepas endorphin. Endorphin akan berperan sebagai neuromodulator dan menghambat pengiriman pesan nyeri.

Selain dari tindakan pengurangan nyeri, perawat juga melakukan tehnik pengurangan rasa cemas yang dialami oleh klien. Tindakan yang dilakukan ialah relaksasi nafas dalam, hal tersebut sangat membantu klien dalam mengurangi rasa cemas. Tindakan relaksasi nafas dalam ini dilakukan selama $1 \mathrm{x} /$ hari selama bertemu dengan pasien setelah dilakukan pijat punggung sampai pinggang. Hasilnya ialah klien lebih rileks, nyaman dan dapat istirahat pada malam hari.

Adapun pada masalah mual-muntah yang sering dialami oleh klien kanker servik yang menjalani pengobatan kemoterapi, perawat memberikan implementasi berupa memberikan edukasi kepada keluarga dan klien dalam mengkonsumsi air hangat serta mengatur nutrisi yang dikonsumsi klien agar mengurangi rasa mual sampai menyebabkan muntah pada klien. Sedangkan pada diagnosa anemia disebabkan kurangnya $\mathrm{Hb}$ pada klien, perawat melakukan tindakan pemberian transfuse darah sebagai bentuk upaya pemulihan pada pasien dengan kolaborasi tim medis. Selain iu perawat memberikan edukasi pentingnya peran keluarga dalam membantu memenuhi nutrisi untuk menambah kadar $\mathrm{Hb}$ dalam darah untuk klien. Perawat berkolaborasi dengan ahli gizi dalam membantu pemenuhan nutrisi pada pasien kanker servik dengan anemia.

\section{Analisis Tindakan Keperawatan sesuai Hasil Penelitian}

Pada kasus kanker servik yang dialami oleh beberapa klien yang telah dilakukan wawancara, didapatkan hasil bahwa klien mengalami beberapa masalah kesehatan, salah satunya ialah rasa nyeri pada bagian punggung sampai pinggang, terkadang hanya didaerah pinggang saja. Hal ini menjadi sebuah masalah pada klien dan menjadi beban kerja bagi perawat, sehingga peneliti memberikan inovasi berupa pijat pinggang 
atau sering disebut tindakan "Slow Stroke Back Massage", tindakan pijat pinggang selama kurang lebih 10-15 menit ini mampu mengurangi nyeri yang dirasakan klien dengan kanker servik, namun tentu saja skala nyeri yang dirasakan masih dalam kisaran sedang sampai ringan. Tindakan pijat pinggang ini mampu mengurangi skala nyeri yang dirasakan pada ketiga klien yang merupakan responden penelitian. Dengan skala nyeri dari sedang sampai ringan (5-3) yang telah diukur menggunakan "Numeric Rating Scale" pada klien dengan kanker servik didapatkan hasil siginifikan bahwa terdapat penurunan skala nyeri. Hasil penelitian ini didukung oleh penelitian Setyowati (2019) dengan judul penelitian "Efektivitas Tindakan Slow Stroke Back Massage Dengan Aroma Terapi Lavender Dalam Menurunkan Nyeri Pinggang Pada Klien Dengan Kanker Servik" dengan 3 responden penelitian, yang menunjukkan hasil bahwa terdapat penurunan skala nyeri, dari nyeri dengan skala 5 menjadi skala 4 . Hal ini juga didukung oleh penelitian yang dilakukan oleh Ningrum, dkk (2019) yang berjudul "Efektivitas Tehnik Slow Stroke Back Massage Pada Nyeri Ibu Post Section Caesaria" dengan 10 responden ibu postpartum menunjukkan hasil bahwa terdapat perbandingan antara skala nyeri sebelum dilakukan tindakan pijat dengan sesudah dilakukan tindakan pijat pinggang berupa penurunan skala nyeri yang dirasakan beberapa responden, dari skala 5 menjadi skala 3. Adapun penelitian lain dengan hasil sama yaitu berfokus pada penurunan nyeri disminore, dilakukan oleh Priscilla (2017) pada judul penelitian "Pengaruh Stimulus Kutaneus Slow Stroke Back Massage Pada Nyeri Disminore Primer Mahasiswa Stikes Muhammadiyah Padang" dengan 12 responden menunjukkan hasil bahwa terdapat penurunan skala nyeri dari skala 5 menjadi skala 3, yang dibuktikan melalui observasi pada kelompok responden selama 1 minggu masa observasi. Penelitian pendukung lain yang menggunakan tehnik "Slow Stroke Back Massage" yaitu penelitian yang dilakukan oleh Sumadi, dkk (2020) yang berjudul "Pemanfaatan Tehnik
Relaksasi Massage Punggung Dalam Penurunan Nyeri Pada Asuhan Keperawatan Pasien Hipertensi" dilakukan pada 3 responden penelitian dengan perlakuan selama 3 hari menunjukkan hasil bahwa terdapat penurunan tekanan darah dan penurunan skala nyeri pada klien dengan hipertensi, dari tekanan darah 140/80 $\mathrm{mmHg}$ menjadi $130 / 90 \mathrm{mmHg}$, dan dengan skala nyeri 4 menjadi skala 3.

Adapun pada penelitian lain yang mana nyeri akut dikarenakan oleh faktor post operasi yaitu penelitian yang dilakukan oleh Nuhanifah, dkk (2020) yang berjudul "Pengaruh Pemberian Massase Punggung (Slow Stroke Back Massage) Menggunakan Aroma Terapi Lavender Terhadap Penurunan Intensitas Nyeri Pada Pasien Post Laparatomi Eksplorasi” dengan tehnik purposive sampling dan uji Wilcoxon menunjukkan hasil signifikan yaitu $p$-value $0,001<\alpha 0,05$ yang dimana rata-rata pada kelompok sebelum dilakukan tindakan dengan skala nyeri sedang yaitu 4-5 sedangkan pada kelompok yang sudah dilakukan tindakan menunjukkan penurunan skala nyeri yaitu 32, sehingga dapat disimpulkan terdapat penurunan skala nyeri setelah dilakukan tindakan pijat punggung sampai pinggang.

Dari beberapa hasil penelitian diatas dapat menjadi acuan bahwa tindakan "Slow Stroke Back Massage" sangat berpengaruh dalam penurunan skala nyeri pada klien dengan keluhan utama nyeri akut, berikut rincian hasil penerapan tindakan pada ketiga klien yang menjadi responden penelitian dengan tindakan nonfarmakologi "Slow Stroke Back Massage" yang dilakukan peneliti ialah pada klien 1 dengan skala nyeri sebelum dilakukan tindakan non farmakologi "Slow Stroke Back Massage" yaitu skala 4 yang artinya skala nyeri sedang, sedangkan setelah dilakukan inovasi tindakan nonfarmakologi "SSBM" selama 3 hari masa perawatan menjadi skala 2 yang artinya skala nyeri ringan, penurunan skala nyeri yang dirasakan klien didukung oleh adanya partisipasi positive dari pihak keluarga klien sehingga klien mampu mengonrol rasa nyeri dengan mandiri dan tidak bergantung pada analgetik. Hal tersebut dapat dipadukan 
dengan hasil penelitian yang dilakukan oleh Puspitasari (2018) dengan judul penelitian "Hubungan Dukungan Suami Dan Keluarga Dengan Intensitas Nyeri Persalinan Kala 1", dengan hasil penelitian yaitu terdapat hubungan dukungan suami dan keluarga dengan hasil uji analisis bivariate p-value < $0,05(0,018)$, nilai koefisien korelasi yaitu (0,396) menunjukkan hubungan negative dimana semakin tinggi dukungan suami dan keluarga maka akan semakin rendah intensitas nyeri yang dirasakan oleh ibu bersalin. Sehingga dapat disimpulkan bahwa dukungan keluarga sangat mempengaruhi penurunan intensitas atau skala nyeri yang dirasakan oleh klien baik nyeri patologis ataupun nyeri fisiologis.

Selanjutnya pada klien 2, dengan skala nyeri sebelum dilakukan tindakan non farmakologi "Slow Stroke Back Massage" yaitu skala 5 yang artinya skala nyeri sedang, sedangkan setelah dilakukan inovasi tindakan nonfarmakologi "SSBM" selama 3 hari masa perawatan menjadi skala 3 yang artinya skala nyeri ringan, penurunan skala nyeri pada klien 2 berbeda dengan klien 1 dikarenakan pada klien 2 memiliki karakteristik yang berbeda dimana klien 2 lebih cenderung dengan kondisi psikologis yang kurang stabil, dikarenakan kurangnya dukungan keluarga serta faktor ekonomi yang minim. Hal tersebut sangat mempengaruhi keberhasilan tindakan untuk mengurangi skala nyeri yang dirasakan klien, karena faktor psikologis sangat berkaitan erat dengan penurunan gejala yang dirasakan klien. Hal tersebut berbanding terbalik dengan hasil penelitian Rini (2018) dengan judul "Penurunan Nyeri Pada Ibu Post Section Caesaria Pasca Intervensi Biologic Nurturing Baby Led Feeding" menunjukkah hasil bahwa nyeri pada ibu post section caesaria dirasakan dapat menganggu kondisi fisik maupun psikologis pada ibu pasca bersalin. Hal tersebut bertolak belakang dengan hasil penelitian yang telah dilakukan dimana klien 2 mengalami kondisi psikologis yang kurang stabil sehingga kurang dalam penerimaan penyakit serta rasa nyeri yang dialaminya.,Disini peneliti dapat menyimpulkan bahwa kondisi fisik maupun psikologis berkaitan erat dengan apapun yang terjadi pada diri individu, dengan kata lain kondisi psikologis sangat dipengaruhi oleh faktor internal seperti penyakit ataupun faktor eksternal seperti hubungan sosial dengan orang lain ataupun dengan keluarga terdekat.

Adapun pada klien 3 dengan skala nyeri sebelum dilakukan tindakan non farmakologi "Slow Stroke Back Massage" yaitu skala 5 yang artinya skala nyeri sedang, sedangkan setelah dilakukan inovasi tindakan nonfarmakologi "SSBM" selama 3 hari masa perawatan menjadi skala 2 yang artinya skala nyeri ringan, hal tersebut memilki perbedaan dari klien 1 dan klien 2 dimana klien 3 masih mampu mengontrol nyeri pinggang yang dirasakannya, namun klien 3 belum mampu mengonrol rasa cemas akan penyakit yang dialaminya, sehingga selain melakukan tindakan pengurangan nyeri peneliti juga melakukan tehnik ditraksi pada klien agar klien lebih merasa tenang dan mampu mengalihkan rasa nyeri yang dirasakannya. Hal tersebut didukung oleh penelitian yang dilakukan oleh Juanita (2015) dengan judul "Tehnik Distraksi Audio Visual Untuk Menurunkan Nyeri Serta Rasa Cemas Pada Anak Sekolah Yang Menjalani Sirkumsisi" dari 5 responden sebagai subyek penelitian terdapat 3 responden mengalami penurunan rasa kecemasan sehingga dapat mengalihkan rasa nyeri yang dirasakan responden. Dari hasil penelitian serta jurnal acuan tersebut dapat disimpulkan bahwa kecemasan berkaitan erat dengan respon nyeri yang dirasakan oleh seseorang dengan gangguan fisiologis ataupun patologis.

\section{KESIMPULAN}

Implementasi keperawatan yang dilakukan pada pasien kanker serviks yaitu menajemen nyeri, termasuk mengajarkan dan membimbing terapi "slow stroke back massage" pada ketiga klien serta keluarga yang telah bersedia dilakukan terapi tersebut. Pelaksanaan tindakan dilakukan selama 1x24 jam selama 3 hari masa perawatan, tehnik pijat punggung sampai pinggang ini dilakukan kurang lebih selama 10-15 menit dengan frekuensi $1 \mathrm{x}$ /hari dan dalam tempo 3 
hari masa perawatan. Implementasi nonfarmakologi berupa tindakan "SSBM" atau pijat punggung sampai pinggang sangat efektif dilakukan pada klien dengan keluhan nyeri pinggang. Observasi selama 3 hari dapat membuahkan hasil dengan penurunan nyeri yang signifikan pada ke-3 klien, dengan penurunan skala 1-2, diukur menggunakan instrument skala nyeri "Numeric Rating Scale". Setelah dilakukan terapi semua klien merasa lebih nyaman, rileks serta dapat berisitirahat dengan tenang dimalam hari. Hasil penelitian ini tidak berpengaruh dengan diberikannya terapi farmakologi sebagai pembantu pengurangan nyeri akut pada klien dengan kanker servik.

\section{DAFTAR PUSTAKA}

Hermanto. (2020). "Upaya Penerapan Penurunan Nyeri Pada Pasien Post Operasi Fraktur Femur".

Juanita, (2015). "Tehnik Distraksi Audio Visual Untuk Menurunkan Nyeri Serta Rasa Cemas Pada Anak Sekolah Yang Menjalani Sirkumsisi”

(Kozier, 2011).

Ningrum, dkk (2019). "Efektivitas Tehnik Slow Stroke Back Massage Pada Nyeri Ibu Post Section Caesaria"

Dewi Nuhanifah., dkk (2020) yang berjudul "Pengaruh Pemberian Massase
Punggung (Slow Stroke Back Massage) Menggunakan Aroma Terapi Lavender Terhadap Penurunan Intensitas Nyeri Pada Pasien Post Laparatomi Eksplorasi”

(Potter \& Perry, 2010).

Priscilla, Vetty; Afriyanti, Esi; (2017). Pengaruh Stimulus Kutaneus Slow Strike Back Masage Terhadap Nyeri Dismenore Primer Pada Mahasiswi Stikes Amanah Padang. NERS: Jurnal Keperawatan, Volume 13, No., 2, Oktober 2017, (Hal 96-104).

Elika Puspitasari (2018) dengan judul penelitian "Hubungan Dukungan Suami Dan Keluarga Dengan Intensitas Nyeri Persalinan Kala 1",

Setyowati, Sri; Rahmawati, Anik; Sumarsih; Widjatiningsih, Maria Indri. (2019) "Efektivitas Tindakan Slow Stroke Back Massage Dengan Aroma Terapi Lavender Dalam Menurunkan Nyeri Pinggang Pada Klien Dengan Kanker Servik.

Sumadi, Amelia Rifki, dkk (2020) pada penelitiannya yang berjudul "Pemanfaatan Tehnik Relaksasi Massage Punggung Dalam Penurunan Nyeri Pada Asuhan Keperawatan Pasien Hipertensi" 